\title{
Peningkatan Animo Melanjutkan Pendidikan pada Perguruan Tinggi melalui Bimbingan dan Konseling Pendekatan Konstektual
}

\author{
Tarkinah \\ Guru Bimbingan dan Konseling \\ SMA Negeri 1 Salem Kabupaten Brebes
}

\author{
SMA Negeri 1 Salem \\ Guru SMA Negeri 1 Salem Kabupaten Brebes
}

\begin{abstract}
Abstrak
Tujuan penelitian ini adalah untuk mengetahui peningkatan animo melanjutkan pendidikan pada perguruan tinggi melalui bimbingan dan konseling pendekatan kontekstual. Berdasarkan hasil penelitian yang telah dilaksanakan terlihat adanya peningkatan yang signifikan terhadap minat karir siswa untuk pendidikan lanjutan ke Perguruan Tinggi, terlihat dari hasil evaluai siklus I dan siklus II, minat siswa pada pendidikan lanjutan ke Perguruan Tinggi pada siklus I sebanyak 16 orang siswa meningkat pada siklus II sebanyak 33 orang siswa atau 42,11\% meningkat pada siklus II menjadi 86,84\% dari jumlah siswa keseluruhan meningkat $44,73 \%$, peminatan siswa pada karir bekerja pada siklus I sebanyak 15 orang siswa menurun pada siklus II sebanyak 4 orang siswa atau 39,47\% menurun pada siklus II menjadi $10,53 \%$ dari jumlah siswa keseluruhan menurun $28,94 \%$, dan banyaknya siswa yang belum dapat menentukan minat karir lanjutan pada siklus I sebanyak 7 orang siswa menurun pada sikuls II sebanyak 1 orang atau 18,42\% menurun pada siklus II menjadi $2,63 \%$ dari jumlah siswa keseluruhan menurun $15,79 \%$.
\end{abstract}

Kata Kunci : Bimbingan dan Konseling, Minat, Pendekatan Konstekstual, Perguruan Tinggi

\begin{abstract}
The purpose of this study was to determine the increase in interest in continuing education at tertiary institutions through contextual approach guidance and counseling. Based on the results of research that has been carried out, it is seen that there is a significant increase in the career interests of students for further education to Higher Education, as seen from the results of the evaluation cycle I and cycle II, the interest of students in further education to Higher Education in the first cycle of 16 students increased in the cycle II as many as 33 students or $42.11 \%$ increased in cycle II to $86.84 \%$ of the total number of students increased by $44.73 \%$, specialization of students in working careers in cycle I as many as 15 students decreased in cycle II by 4 students or $39.47 \%$ decreased in cycle II to $10.53 \%$ of the total number of students decreased by $28.94 \%$, and the number of students who have not been able to determine further career interest in cycle I by 7 students decreased in cycle II by 1 person or $18,42 \%$ decreased in cycle II to $2.63 \%$ of the total number of students decreased by $15.79 \%$.

Keywords: Guidance and Counseling, Interests, Contextual Approach, Higher Education
\end{abstract}




\section{PENDAHULUAN}

Terlepas dari euforia kelulusan SMA/SMK atau sederajat. Persoalan lain yang dihadapi para siswa dan orang tua adalah tingginya target kelulusan yang dipatok pihak sekolah. Seolah-olah menjadi hak sekolah untuk mengharuskan semua para muridnya lulus demi mengejar pamor di masyarakat dan akreditasi. Sementara di satu sisi pemerintah masih berkutat pada standar UN sebagai verifikasi akhir kelulusan para siswa. Irisan dua kepentingan ini menjadi beban tambahan buat para siswa yang tak hanya memikirkan strategi belajar dan pilihan yang bakal dipilih ketika lulus sekolah.

Puncak segala kegelisahan yang dialami oleh siswa SMA bukan terletak pada saat perjuangan menghadapi Ujian Nasional, namun ada momen yang lebih dari itu. Kelas XII atau kelas 3 SMA adalah saat-saat di mana kebanyakan siswa mendadak menjadi rajin beribadah. Karena banyak anggapan dari siswa di sinilah saat penentuan nasib masa depan, sebuah batu pijakan yang bisa membuat seseorang sukses, atau justru sebaliknya.

Maka dengan adanya layanan Bimbingan dan Konseling diharapkan mampu memberikan wawasan dan pengetahuan terkait Perguruan Tinggi sesuai dengan minat karir dari masing-masing siswa itu sendiri. Semenjak awal siswa di upayakan untuk dapat mengembangkan baik kemampuan masing-masing bidang maupun di arahkan sesuai dengan minat siswa yang di harapkan dari setiap individu tumbuh minat dengan segala pertimbangan untuk masa depan. Layanan Bimbingan dan Konseling lebih mengarahkan siswa untuk melanjutkan pendidikan ke jenjang yang lebih tinggi dengan maksud selain dari kompetensi yang sesuai dengan hal-hal yang pernah di pelajari selama menjalani pendidikan di perguruan tinggi, serta memberikan gambaran bahwa jenjang karir di dunia kerja lebih memprioritaskan lulusan dari perguruan tinggi maupun kursus binaan pengembangan kompetensi.

Prayitno dan Erman Amti dalam Bimo Walgito (2010), Bimbingan adalah proses pemberian bantuan yang dilakukan oleh orang yang ahli kepada seseorang atau beberapa orang individu, baik anak-anak, remaja, atau orang dewasa; agar orang yang dibimbing dapat mengembangkan kemampuan dirinya sendiri dan mandiri dengan memanfaatkan kekuatan individu dan sarana yang ada dan dapat dikembangkan berdasarkan norma-norma yang berlaku. Donald E. Super dalam Sukardi (1994) berpendapat bahwa Karir adalah sebagai suatu rangkaian pekerjaan-pekerjaan, jabatan-jabatan, dan kedudukan yang mengarah pada kehidupan dalam dunia kerja.

Pada kenyataannya masih banyak dari siswa-siswi SMA Negeri 1 Salem yang belum banyak menunjukan adanya minat untuk melajutkan pendidikan ke jenjang perguruan tinggi, hal ini terjadi karena banyak hal faktor yang mempengaruhi nya, seperti kurangnya informasi yang cukup jelas, faktor ekonomi keluarga yang kurang menunjang, adanya keinginan untuk bekerja ke luar kota maupun ke luar pulau hanya karena ajakan dari kerabat. Hal ini terlihat dari hasil pengamatan lulusan setiap tahunnya yang berminat untuk melanjutkan study ke jenjang pendidikan perguruan tinggi tidak lebih dari $40 \%$, sementara harapan dari sekolah adalah banyak dari siswa yang melanjutkan ke jenjang perguruan tinggi, dengan harapan lulusan dari perguruan tinggi tentunya akan lebih siap untuk berada di tengah persaingan karier yang lebih tinggi yang tentunya akan sangat berbeda persaingannya dengan karier bekerja dengan yang hanya lulusan SMA.

Menurut Slameto (2010) minat adalah kecenderungan yang tetap untuk memperhatikan dan mengenang beberapa kegiatan. Kegiatan yang diminati seseorang diperhatikan terus menerus yang disertai dengan rasa senang. Jadi berbeda dengan perhatian karena perhatian bersifat sementara (tidak dalam waktu lama) dan belum tentu diikuti dengan perasaan senang. Sedangkan minat selalu diikuti perasaan senang dan disitu diperoleh kepuasan. Menurut Crow and row dalam Djaali mengatakan bahwa " minat berhubungan dengan gaya gerak yang mendorong seseorang untuk menghadapi atau berurusan dengan orang, benda, kegiatan, pengalaman yang dirangsang oleh kegiatan itu sendiri (Djaali, 2007).

Fenomena yang sering terjadi adalah banyak dari siswa yang telah lulus tidak melanjutkan ke pendidikan ke perguruan tinggi dan tidak bekerja, beberapa faktor di antaranya adalah karena kurangnya keterampilan yang dimiliki siswa sehingga sulit bersaing di lapangan kerja sesuai dengan kebutuhan dari beberapa perusahaan yang di tuju oleh siswa tersebut. Bila masalah tersebut tidak ditangani secara baik maka akan berdampak negatif bagi beberapa pihak yang bersangkutan diantaranya yang pertama, bagi siswa yaitu kurangnya pengetahuan siswa tentang perguruan tinggi yang meliputi tujuan, manfaat, prospek karir setelah 
lulus dari perguruan tinggi. Kedua, bagi sekolah terutama guru BK jika kurang maksimalnya layanan informasi mengenai pendidikan lanjutan tidak segera diatasi maka pengetahuan, pemahaman, bakat, dan kompetensi siswa tidak akan berkembang secara optimal serta pemberian layanan informasi menjadi tidak bervariatif.

Untuk mengatasi hal tersebut dibutuhkan layanan informasi karier mengenai pendidikan lanjutan ke Perguruan Tinggi sehingga siswa mempunyai gambaran yang luas tentang minat karier. Disamping itu siswa juga tahu tujuan dan manfaat melanjutkan pendidikan ke perguruan tinggi serta mengetahui bagaimana pengaruhnya terhadap masa depan siswa. Cara penyampaian yang dilakukan dengan memanfaatkan media dan metode yang manarik perhatian siswa dalam pelaksanaan layanan. Pendekatan kontekstual sudah lama dikembangkan oleh John Dewey pada tahun 1916, yaitu sebagai filosofi belajar yang menekankan pada pengembangan minat dan pengalaman siswa. Kontekstual (Contextual Teaching and Learning) dikembangkan oleh The Washington State Consortium for Contextual Teaching and Learning, yang bergerak dalam dunia pendidikan di Amerika Serikat.

Tujuan penelitian ini adalah untuk mengetahui peningkatan animo melanjutkan pendidikan pada perguruan tinggi melalui bimbingan dan konseling pendekatan kontekstual.

\section{METODE}

Subjek Penelitian dalam Penelitian ini adalah siswa kelas X MIPA SMA Negeri 1 Salem Kecamatan Salem Kabupaten Brebes. Jumlah siswa yang menjadi subjek penelitian ini adalah 38 orang siswa, yang terdiri dari 7 siswa Laki-laki dan 31 siswa perempuan. Teknik pengumpulan datanya melalui angket, wawancara dan observasi. Teknik analisis data yang digunakan dalam penelitian ini adalah analisis kualitatif dan analisis kuantitatif. Analisis data kualitatif dilakukan pada data kualitatif yaitu data yang memberikan informasi berbentuk kalimat yang memberikan gambaran analisis hasil pengamatan proses layanan informasi karier. Gambaran juga diperoleh dari tingkat presentase yang didapat kemudian ditafsirkan dalam bentuk kategori. Sedangkan analisis data kuantitatif dilakukan dengan menggunakan statistik deskriptif prosentase, statistik deskriptif yang menyajikan data dalam bentuk data presentase. Statistik deskriptif adalah statistik yang digunakan untuk menganalisis data dengan cara mendeskripsikan atau menggambarkan data yang telah terkumpul sebagaimana adanya tanpa bermaksud membuat kesimpulan yang berlaku umum atau generalisasi (Sugiyono, 2010).

Prosedur penelitian sebagai berikut :

\section{a. Siklus 1}

1) Perencanaan

Penelitian ini dilaksanakan dua siklus, dengan rincian: Siklus 1 dilakukan 2 pertemuan, pertemuan ke 1 dilakukan tanggal 23 Agustus 2016, pertemuan ke 2 dilakukan pada tanggal 30 Agustus 2016, evaluasi dilakukan tanggal 6 September 2016.

\begin{tabular}{|l|l|}
\hline Tanggal Tatap Muka & Materi \\
\hline 23 Agustus 2016 & a) Gejala kesulitan belajar \\
& b) Faktor - faktor yang menyebabkan \\
& cesulitan belajar \\
& c) Langkah mengatasi kesulitan belajar \\
& d) Indikator pemecahan masalah \\
\hline 30 Agusuts 2016 & a) Memahami Perguruan Tinggi sejak \\
& b) Bentuk Perguruan Tinggi di Indonesia \\
& c) Status kepemilikan Perguruan Tinggi di \\
& d) Nama program di perguruan tinggi \\
& e) Apabila ingin kuliah di luar negeri \\
\hline
\end{tabular}




\section{2) Pelaksanaan}

Siklus 1 dilakukan 2 pertemuan, pertemuan ke 1 dilakukan tanggal 23 Agustus 2016, pertemuan ke 2 dilakukan pada tanggal 30 Agustus 2016. Langkah-langkah kegiatan pelaksanaan adalah sebagi berikut:

\section{Siklus I}

\section{Pertemuan pertama dan kedua \\ Pendahuluan}

a) Guru Bimbingan Konseling melakukan Presensi pada Siswa

b) Guru Bimbingan Konseling membahas tentang deskripsi karir

\section{Kegiatan Inti}

a) Melakukan analisis subjek penelitian mengenai minat studi lanjut ke Perguruan Tinggi pada kondisi awal.

b) Diagnosis kondisi awal yaitu melakukan identifikasi masalah dan menentukan faktor penyebab masalah.

\section{Mengamati}

a) Guru Bimbingan Konseling memberikan materi dulu kemudian siswa disuruh untuk mengamati tentang materi yang disampaikan berupa gambar, power point, dll .

b) Guru Bimbingan Konseling memberikan layanan informasi karir sesuai rencana awal yang sudah di sediakan berdasarkan diagnosis kondisi awal

c) Guru Bimbingan Konseling memberikan pandangan tentang pendidikan lanjutan dari tingkat SMA ke Perguruan Tinggi

d) Guru Bimbingan Konseling memberikan gambaran dari hal-hal yang pernah siswa jumpai, baik dari masyarakat di lingkungan siswa yang melanjutkan pendidikan ke Perguruan Tinggi dan yang menganggur.

\section{Bertanya}

Guru Bimbingan Konseling bertanya kepada siswa tentang apa yang diketahuinya dari materi yang disampaikan .

\section{Menalar}

Siswa memberikan persepsi atau pendapat tentang materi - materi yang disampaikan

\section{Mencoba}

Siswa diajak untuk mencoba tentang materi yang disampaikan kemudian bisa diterapkan pada kehidupan sehari - hari .

\section{Jejaring Sosial}

Guru Bimbingan Konseling mengajak siswa untuk memberikan pendapat tentang pandangan pentingnya pendidikan lanjutan ke Perguruan Tinggi

\section{Kegiatan Penutup :}

a) Melakukan refleksi materi yang telah dibahas.

b) Guru Bimbingan Konseling mengaitkan gambaran sebelumnya dengan pendidikan lanjutan ke Perguruan Tinggi

c) Memberikan kesempatan kepada siswa untuk bertanya mengenai materi yang kurang dimengerti.

\section{3) Pengamatan}

Salah satu langkah penting dalam penelitian tindakan Bimbingan Konseling adalah melakukan pengamatan. Untuk proses pengamatan ini, guru Bimbingan Konseling menganalisa dari hasil observasi Bimbingan konseling layanan informasi. Pengamatan dilaksanakan selama proses perbaikan kegiatan layanan berlangsung dengan mengacu kepada lembar pengamatan yang telah dipersiapkan sebelumnya.

4) Refleksi

Refleksi dilaksanakan dengan melihat hasil evaluasi dan hasil pengamatan untuk melakukan analisis tentang tindakan yang telah dilaksanakan, membahas kendala-kendala yang ditemukan berkaitan dengan tindakan yang akan dilakukan dan melakukan interpretasi, pemaknaan, serta penyimpulan data yang selanjutnya dilihat relevansinya dengan rencana yang telah diterapkan. Setelah pelaksanaan siklus I dari pengamatan diperoleh data yang menunjukkan respon siswa terhadap layanan informasi Perguruan Tinggi 
yang sudah dilakukan. Pada siklus I layanan informasi dibatasi sehingga siswa kesulitan dalam berpikir cepat karena faktor usia yang masih termasuk ke dalam usia dini (pemula), maka pada siklus II akan dicoba lagi dengan memberi waktu yang cukup lama.

\section{b. Siklus II}

\section{1) Perencanaan}

Siklus 2 dilakukan 2 pertemuan, pertemuan ke 1 dilakukan tanggal 13 September 2016, pertemuan ke 2 dilakukan pada tanggal 20 September 2016, dan evaluasi dilakukan tanggal 27 September 2016.

\begin{tabular}{|l|l|}
\hline Tanggal Tatap Muka & Materi \\
\hline 13 September 2016 & a) Mengenal kurikulum \\
& b) Kelompok peminatan di SMA. \\
& c) Struktur kurikulum SMA \\
& d) Persyaratan pengelompokan peminatan \\
\hline 20 September 2016 & a) Bekerja dan hidup \\
& b) Makna bekerja \\
& c) Lapangan kerja \\
& d) Ke mana akan bekerja? \\
\hline
\end{tabular}

2) Pelaksanaan

Siklus 2 dilakukan 2 pertemuan, pertemuan ke 1 dilakukan tanggal 13 September 2016, pertemuan ke 2 dilakukan pada tanggal 20 September 2016, Langkah-langkah kegiatan pelaksanaan adalah sebagi berikut:

\section{Siklus II}

\section{Pertemuan ketiga dan keempat}

\section{Pendahuluan}

a) Guru Bimbingan Konseling melakukan Absensi pada Siswa

b) Guru Bimbingan Konseling membahas tentang pemilihan jenjang karir

\section{Kegiatan Inti}

a) Melakukan analisis subjek penelitian mengenai minat studi lanjut ke Perguruan tinggi pada kondisi awal.

b) Diagnosis kondisi awal yaitu melakukan identifikasi masalah dan menentukan faktor penyebab masalah.

\section{Mengamati}

a) Guru Bimbingan Konseling memberikan layanan informasi terkait dorongan pemilihan jalur karir baik dari pendidikan lanjutan ke perguruan tinggi, lembaga kursus, kedinasan, sekolah sipil dan militer, wirausaha, dan swasta.

b) Guru Bimbingan Konseling memberikan layanan informasi pengalaman baik dari Guru Bimbingan Konseling, alumnis, maupun dari pandangan siswa terhadap masyarakat lingkungan sekitar

c) Guru Bimbingan Konseling memberikan pandangan tentang pendidikan lanjutan

d) Guru Bimbingan Konseling memberikan gambaran dari hal-hal yang pernah siswa jumpai, baik dari masyarakat di lingkungan siswa yang melanjutkan pendidikan ke jenjang Perguruan Tinggi dan yang menganggur.

\section{Bertanya}

Guru Bimbingan Konseling bertanya kepada siswa tentang apa yang diketahuinya dari materi yang disampaikan.

\section{Menalar}

Siswa memberikan persepsi atau pendapat tentang materi - materi yang disampaikan

\section{Mencoba}

Siswa diajak untuk mencoba tentang materi yang disampaikan kemudian bisa diterapkan pada kehidupan sehari - hari . 


\section{Jejaring Sosial}

Guru Bimbingan Konseling mengajak siswa untuk memberikan pendapat tentang pandangan pentingnya pendidikan lanjutan ke Perguruan Tinggi.

\section{Kegiatan Penutup :}

a) Melakukan refleksi materi yang telah dibahas.

b) Guru mengaitkan gambaran sebelumnya dengan pendidikan lanjutan ke Perguruan Tinggi

c) Memberikan kesempatan kepada siswa untuk bertanya mengenai materi yang kurang dimengerti.

\section{3) Pengamatan}

Langkah-langkah pembelajaran masih tetap sama seperti pada siklus ke I. Selama pelaksanaan siklus ke II ini siswa kelihatan lebih antusias. Dari hasil evaluasi ternyata menunjukan apresiasi dalam menentukan jenjang karir dan peminatan sesuai dengan minat dan bakat siswa.

4) Refleksi

Melihat dari evaluasi dari siklus ke I dan siklus ke II tersebut sangat memuaskan. Dapat diamati bahwa layanan Bimbingan dan Konseling layanan informasi melalui pendekatan Kontekstual sangat efektif digunakan dalam meningkatkan animo siswa melanjutkan pendidikan ke Perguruan Tinggi karena dapat menarik perhatian siswa untuk belajar, siswa saling bertukar pikiran, berdiskusi dan lebih memahami pembelajaran yang dihadapinya.

\section{HASIL}

Penelitian ini dilaksanakan dua siklus, dengan rincian: Siklus 1 dilakukan 2 pertemuan, pertemuan ke 1 dilakukan tanggal 23 Agustus 2016, pertemuan ke 2 dilakukan pada tanggal 30 Agustus 2016, evaluasi dilakukan tanggal 6 September 2016.

Tabel 4.1

Hasil Evaluasi Siklus I

\begin{tabular}{|c|c|c|c|c|}
\hline \multirow{2}{*}{ No } & Keterangan & \multicolumn{3}{|c|}{ Minat Karier } \\
\cline { 3 - 5 } & & Kuliah & Bekerja & Tidak Tahu \\
\hline 1 & Peminatan Karir & 16 Siswa & 15 Siswa & 7 Siswa \\
\hline 2 & Persentase & $42,11 \%$ & $39,47 \%$ & $18,42 \%$ \\
\hline
\end{tabular}

Berdasarkan hasil dari evalasi siklus I terlihat masih banyak siswa yang memilih jenjang karir setelah lulus dari SMA adalah langsung bekerja, hal ini dipengaruhi oleh banyak faktor diataranya adalah lingkungan tempat siswa tinggal banyak menunjukan bahwa lulusan SMA dapat langsung bekerja. Kebanyakan dari teman-teman siswa di lingkungan tempat tinggalnya lebih memilih bekerja di luar kota, lintas provinsi bahkan di luar negeri. Dengan mindset yang tergambar oleh siswa kebanyakan adalah dengan kemampuan yang siswa dpatkan selama menjalani pendidikan di SMA itu dianggap cukup, selama proses layanan Bimbingan Konseling di siklus I siswa diberikan gambaran melalui layanan informasi dengan menggunakan layanan klasika, sehingga pandangan siswa terkait pentingnya pendidikan lanjutan masih banyak yang mengabaikan. Hal ini terlihat dari hasil evaluasi siklus 1 jumlah siswa yang memilih untuk melanjutkan pendidikan ke perguruan tinggi sebanyak 16 orang siswa atau $42,11 \%$ dari jumlah siswa keseluruah, siswa yang memilih minat untuk langsung bekerja sebanyak 15 orang siswa atau 39,47\% dari jumlah siswa keseluruhan, dan siswa yang belum mendapatkan gambaran minat karir lanjutan setelah lulus dari SMA nanti sebanyak 7 orang siswa atau $18,42 \%$ dari jumlah siswa keseluruhan.

Siklus 2 dilakukan 2 pertemuan, pertemuan ke 1 dilakukan tanggal 6 September 2016, pertemuan ke 2 dilakukan pada tanggal 13 September 2016, dan evaluasi dilakukan tanggal 20 September 2016.

Tabel 4.2 
Hasil Evaluasi Siklus II

\begin{tabular}{|c|c|c|c|c|}
\hline \multirow{2}{*}{ No } & \multirow{2}{*}{ Keterangan } & \multicolumn{3}{|c|}{ Minat Karier } \\
\cline { 3 - 5 } & & Kuliah & Bekerja & Tidak Tahu \\
\hline 1 & Peminatan Karir & 33 Siswa & 4 Siswa & 1 Siswa \\
\hline 2 & Persentase & $86,84 \%$ & $10,53 \%$ & $2,63 \%$ \\
\hline
\end{tabular}

Berdasarkan hasil evaluasi siklus II terlihat perubahan paradigma peserta didik tentang pentingnya pendidikan lanjutan ke Perguruan Tinggi. Selama proses Bimbingan Konseling layanan informasi minat karier yang dilaksanakan dengan pendekatan Kontekstual siswa terlihat lebih antusias dengan layanan informasi yang diberikan guru Bimbingan Konseling, informasi yang di sajikan dalam kelas lebih mengutamakan membuka wawasan bahwa pentingnya pendidikan lanjutan untuk menunjang kemampuan bakat dan minat peserta didik dalam menentukan minat karir kedepannya. Hal ini terlihat dari banyaknya siswa yang memilih untuk minat pendidikan lanjutan ke Perguraun Tinggi sebanyak 33 orang siswa atau $86,84 \%$ dari jumlah siswa keseluruhan, siswa yang memilih minat lanjutan untuk langsung bekerja sebanyak 4 orang siswa atau $10,53 \%$ dari jumlah siswa keseluruhan, dan siswa yang belum bisa memutuskan untuk minat karir lanjutan sebanyak 1 orang siswa atau 2,63\% dari jumlah siswa keseluruhan.

Tabel 4.3

Rekapitulasi Data Hasil Evaluasi Siklus I dan Siklus II

\begin{tabular}{|c|c|c|c|c|}
\hline \multirow{2}{*}{ No } & \multirow{2}{*}{ Keterangan } & \multicolumn{3}{|c|}{ Minat Karier } \\
\cline { 2 - 5 } & Keminatan Karir & Kuliah & Bekerja & Tidak Tahu \\
\hline \multirow{2}{*}{1} & Siklus I & & & \\
\cline { 2 - 5 } & Siklus II & 16 Siswa & 15 Siswa & 7 Siswa \\
\cline { 2 - 5 } & Persentase & 33 Siswa & 4 Siswa & 1 Siswa \\
\hline \multirow{2}{*}{2} & Siklus I & & & \\
\cline { 2 - 5 } & Siklus II & $42,11 \%$ & $39,47 \%$ & $18,42 \%$ \\
\cline { 2 - 5 } & & $86,84 \%$ & $10,53 \%$ & $2,63 \%$ \\
\hline
\end{tabular}

\section{PEMBAHASAN}

Secara umum informasi yang didapat peserta didik tentang pentingnya pendidikan lanjutan ke Perguruan Tinggi bisa dikatakan masih kurang karena disebabkan banyak hal, namun faktor yang lebih sering menyebabkan siswa memilih minat karir pada lingkungan bekerja adalah lingkungan tempat tinggal siswa tersebut, dimana banyak teman-teman yang setelah lulus SMA memutuskan untuk bekerja di luar kota, lintas provinsi bahkan di luar negeri tanpa ada kejelasan sebelumnya akan bekerja di bidang apa nantinya, namun karena kebutuhan ekonomi juga yanng mempengaruhi kesenjangan peminatan siswa ke pendidikan lanjutan.

Setelah dilaksanakan layanan informasi oleh guru Bimbingan dan Konseling tentang minat karir peserta didik terkait pentingnya pendidikan lanjutan ke Perguruan Tinggi dan hasilnya menunjukan bahwa antusias siswa menjadi semakin tertarik untuk melanjutkan pendidikan ke Perguruan Tinggi, mengingat perlunya kemampuan yang harus dimiliki siswa untuk karir selanjutnya. 
Tabel 4

Perbandingan Data Hasil Evaluasi Siklus I dan Siklus II

\begin{tabular}{|l|l|l|}
\hline Peminatan & Siklus I & Siklus II \\
\hline Kuliah & 16 siswa & 33 siswa \\
\hline Bekerja & 15 siswa & 4 siswa \\
\hline Tidak Tahu & 7 siswa & 1 siswa \\
\hline
\end{tabular}

Berdasarkan data diatas membuktikan bahwa Pendekatan Kontekstual dapat meningkatkan animo melanjutkan Pendidikan pada Perguruan Tinggi melalui Bimbingan dan Konseling pada Peserta Didik Kelas X SMA Negeri 1 Salem Semester I Tahun Pelajaran 2016/2017, hal ini ditunjukan dari hasil evaluai siklus I dan siklus II, peminatan siswa pada pendidikan lanjutan ke Perguruan Tinggi pada siklus I sebanyak 16 orang siswa meningkat pada siklus II sebanyak 33 orang siswa atau 42,11\% meningkat pada siklus II menjadi $86,84 \%$ dari jumlah siswa keseluruhan meningkat 44,73\%, peminatan siswa pada karir bekerja pada siklus I sebanyak 15 orang siswa menurun pada siklus II sebanyak 4 orang siswa atau 39,47\% menurun pada siklus II menjadi $10,53 \%$ dari jumlah siswa keseluruhan menurun $28,94 \%$, dan banyaknya siswa yang belum dapat menentukan minat karir lanjutan pada siklus I sebanyak 7 orang siswa menurun pada sikuls II sebanyak 1 orang atau 18,42\% menurun pada siklus II menjadi 2,63\% dari jumlah siswa keseluruhan menurun 15,79\%.

\section{SIMPULAN}

Pendekatan Kontekstual dapat meningkatkan animo melanjutkan Pendidikan pada Perguruan Tinggi melalui Bimbingan dan Konseling pada Peserta Didik Kelas X SMA Negeri 1 Salem Semester I Tahun Pelajaran 2016/2017.

\section{SARAN}

Saran-saran yang dapat peneliti sampaikan dalam penelitian ini sebagai berikut: 1) Guru BK senantiasa melakukan inovasi pelayanan bimbingan dan konseling, 2) Kepala Sekolah memberikan dukungan kepada Guru BK melakukan pengembangan diri.

\section{DAFTAR PUSTAKA}

Djaali. 2007. Psikologi Pendidikan. Jakarta : Bumi Aksara.

Slameto. 2010. Belajar dan Faktor-faktor yang Mempengaruhi. Jakarta: Rineka Cipta.

Sugiyono. 2010. Metode Penelitian Kuantitatif-Kualitatifdan R\&D. Bandung: Alfabeta

Sukardi, Dewa Ketut. 1994. Bimbingan Karir Di Sekolah-sekolah. Jakarta : Ghalia Indonesia

Walgito, Bimo. 2010. Bimbingan dan Konseling : Studi \& Karier. Yogyakarta : Penerbit CV Andi Offset. 